(RESEARCH ARTICLE)

\title{
Evaluation of herbicides and manual weed control methods in the establishment of Theobroma cacao L. in Cross River State of Nigeria
}

Ayegboyin Kayode Olufemi, ${ }^{*}$ Adejobi Kayode Babatunde, Olaniyi Olayinka Olufemi, Adeosun Seun Adewale, Ugioro Osasogie, Idrisu Mohammed and Adeleke Sunday Akanji

Cocoa Research Institute of Nigeria, KM 14, Ibadan - Ijebu-Ode Road, Idi-Ayunre, PMB 5422, Ibadan, Nigeria.

Publication history: Received on 01 October 2020; revised on 24 October 2020; accepted on 27 October 2020

Article DOI: https://doi.org/10.30574/wjarr.2020.8.1.0368

\begin{abstract}
Field trial was conducted at the Cocoa Research Institute of Nigeria (CRIN), Ajassor substation, Cross River State, Nigeria between 2015 and 2017 to evaluate the effect of different weed control methods on the growth and yield of cocoa during their early years of establishment. Glyphosate and paraquat were applied at 480, 720, 960 and 1440 gram of active ingredient per hectare using very low volume ( $\mathrm{g}$ a.i. ha ${ }^{-1} \mathrm{vlv}$ ) while manual weeding (i.e. slashing with cutlass) was used as the control. A Nigeria commercial cocoa variety Tc series, also known as 18-month cocoa, was established at a CRIN recommended spacing of $3 \times 3 \mathrm{~m}$, laid out in a Complete Randomized Block Design with four replications. All young cocoa stands were ring weeded at $50 \mathrm{~cm}$ diameter and covered with black polythene bags before the spraying of herbicides during the first six months of establishment to reduce injury that could result from the drifting of herbicide solution to plants during their early growth stage. Data was collected on the plant height, stem girth and number of leaves of cocoa plants while the cocoa dry beans weight and labour cost for each treatment were determined. The results showed that $960 \mathrm{~g}$ a.i. ha-1 vlv was the best herbicide application rate while plots under glyphosate at $960 \mathrm{~g}$ a.i. ha-1 vlv produced significantly higher values of plant height, stem girth and number of leaves at $(p=0.05)$ than both paraquat at $960 \mathrm{~g}$ a.i. ha-1 vlv and manual weeding. Labour cost for controlling weeds with either glyphosate or paraquat at all application rates were considerably lower than cost for control (manual weeding). Glyphosate at $960 \mathrm{~g}^{\mathrm{a} . \mathrm{i}}$. ha-1 $\mathrm{vlv}^{-}$ is recommended for weed control in cocoa plantation because it encouraged higher growth and yield performance of cocoa than other treatments, had considerably cheaper cost of application than paraquat at $960 \mathrm{~g}$ a.i. ha-1 vlv and manual weeding, and it also ensured a weed-free environment over a longer period of time than the other treatments.
\end{abstract}

Keywords: Cocoa; Establishment; Weeds; Labour; Yield

\section{Introduction}

Cocoa tree or cacao is an evergreen tree from the family of Malvaceae, an economically important perennial crop which native to the deep tropical regions of Mesoamerica and grows between 4 to $8 \mathrm{~m}$ tall. Its seeds are known as cocoa beans and are used for beverage, chocolate bars, cocoa wine, cocoa butter, fertilizers, animal feed, among others. The bulk of cocoa production comes from millions of smallholders' farmers in West Africa that produced a whopping 3,504 million tonnes of cocoa beans out of world total of 4,640 million tonnes, about $75.5 \%$ of global cocoa beans production, in the $2017 / 2018$ planting season, Nigeria is currently the $5^{\text {th }}$ largest cocoa beans producer in the world recorded about 255,000 metric tonnes of cocoa beans in 2017/2018 planting season [10]. Despite its importance in Nigeria economy, cocoa production in the country is far below expectation due to numerous factors such as low yielding materials, inadequate soil fertility, attack of pests and diseases and weed infestation [15].

\footnotetext{
${ }^{*}$ Corresponding author: Ayegboyin Kayode Olufemi

Cocoa Research Institute of Nigeria, KM 14, Ibadan - Ijebu-Ode Road, Idi-Ayunre, PMB 5422, Ibadan, Nigeria. 
Weed number, composition and infestation vary greatly from location to location, and compete with cocoa more at early stages of plantation. Due to its fast regenerative capacity and wide adaptation to the environment, weed control is one of the most important factors in successful cocoa establishment [15]. Weed management in cocoa plantation constitutes the greatest problem during the first 3 years of establishment [9]. In a well-established plantation, weed infestations usually decline around fourth to fifth year of establishment when thick canopy coverage and layer of cocoa litter would have been built up. The extent of yield losses of cocoa to weeds infestation depends on the nature, intensity, stage and duration of crop competition with weeds [20]. Losses from weed competition were between 10-25\% of total crop production [8] while 40-60\% of the total production cost excluding the cost of the farmland, is usually spent on manual weeding in some crops [17]. It has also been reported that manual weed control in rehabilitating cocoa accounted for about $23 \%$ of the total labour input [4]. Although, good agricultural practices like cultivation of improved varieties of crop and the adoption of optimal planting density can be related to the relative vigour of cocoa trees [5], improved weed control is highly beneficial to the survival and growth of both cocoa seedlings and its trees on the field [21]. Competitions from weeds must be kept at a minimal level during the early stage of cocoa establishment so as to ensure uniform growth essential for quality early yields that will guarantee good sustainability and profitability of cocoa plants.

Major weed control in cocoa include cultural, mechanical, biological and chemical applications. Manual and mechanical methods are similar in principle as they both involve total removal of weeds. It is believed that combination of two or more methods is necessary for better results considering varying characteristics of weed species. Identification of different weed species occurrence and the choice of the right method and equipment or material are also vital for effective control. Technical know-how on the right choice of sprayer and nozzle designs had been emphasized. Manual weeding is the most common method of weed control in Nigeria with slashing and hoeing being the two major traditional manual weed control methods being used by Nigerian farmers on their cocoa plantations [11]. The backbreaking traditional method is very expensive, labour intensive and highly strenuous. Most often, availability of labour to carry out cultural weed control, as and when due, is usually uncertain, resulting into high loss of yield [1]. Chemical weed control is gradually playing an increasing role in Nigerian agriculture due to increasing widespread dearth of labour required to carry out traditional practices. Yet, there are some thoughts that most herbicides, which could either be a contact (paraquat) or systemic (glyphosate) chemical, have different effects on cocoa, there is an insinuation that they are less safe than manual weeding, especially in view of a very serious damage that could result from an accidental discharge and drifts of these chemical solution on plants. Notwithstanding, Nigeria's drive towards increased cocoa production must involve a systematic approach to weed control based on a good understanding of weed biology and cocoa ecology. Therefore, the objective of this research work was to evaluate the effectiveness and efficiency of different weed control methods on the growth and yield of cocoa in Nigeria.

\section{Material and methods}

The field experiment was conducted at Cocoa Research Institute of Nigeria, Ajassor substation in Cross River State of Nigeria (latitude $5.8504^{\circ} \mathrm{N}$, longitude $8.8142^{\circ} \mathrm{E}$ ) between 2015 and 2017 with treatments laid out in a randomized complete block design and each plot size was 30 x $30 \mathrm{~m}$. A commercial cocoa variety (Tc series or 18-month cocoa) was established at a recommended spacing of $3 \times 3 \mathrm{~m}$ with 4 replications. All young cocoa stands were ring weeded at $50 \mathrm{~cm}$ diameter and covered with black polythene bags before the spraying of herbicides during the $1^{\text {st }}$ six months of field establishment to reduce injury that could result from the drifting of herbicide solution to plants at their early stage of growth. Both glyphosate and paraquat were applied at different rates of 480, 720, 960 and 1440 gram of active ingredient per hectare using very low volume ( $\mathrm{g}$ a.i. ha-1 $\mathrm{vlv}$ ) while manual weeding (slashing with cutlass) was adopted as the control. Applications of herbicides as well as slashing of plot were carried out for times per year, with each application carried out when weeds were about $50 \mathrm{~cm}$ tall or about $100 \%$ ground cover. Other recommended cultural practices necessary for the management of pests and diseases in cocoa were also routinely carried out.

The level of occurrence of different weed species at the experimental site was determined in July of every year, which was the peak of raining season in this area during the period, to show the annual composition of weeds for the first 3 years' of establishment. The cost of each control method was determined as follows:

Cost of herbicide $=$ Cost per litre of either glyphosate or paraquat multiplied by the total number of litres of herbicide used in 3 years. ...1

Cost of labour $=$ Cost per manday multiplied by the total number of mandays used per plot in 3 years.............2

Cost per treatment (herbicide) $=$ Cost of herbicide $(1)+$ Cost of labour (2) ...............

Cost per treatment (manual weeding) $=$ Cost per manday + Total number of mandays used in 3 years.............4 
Data was collected on the plant height, stem girth and number of leaves at an 8-week interval to determine the cocoa growth. The cocoa variety used for the experiment was Tc series, which is also commercially called 18-month cocoa in Nigeria because it starts bearing fruits around one year after transplanting and especially if they had been previously nursed for a minimum of 6 months in the nursery. All the cocoa pods that got ripe after reaching full maturity were harvested and physically counted to know the quantity of fresh pods produced by each tree. The fresh cocoa beans were extracted immediately after their pods had been broken with sticks, fermented and dried to about 8\% moisture content (Aqua-Boy KAM series moisture meter with KAMIII Measuring Range of 2-20\%) to determine cocoa dry beans weights referred to as the cocoa yield in the present study. The appraisal of the weight of dry cocoa beans was done in gram per hectare ( $\mathrm{g} \mathrm{ha}^{-1}$ ) while the first 3 years' accumulated cost of labour for each of the weed control methods were calculated in local currency, Nigerian Naira ( $\mathrm{N}$ ). The weed species at the experimental site were obtained by taking weed samples at random from a $1 \mathrm{~m}^{2}$ quadrat placed randomly 20 times per treatment plot separately in the months of May and October of 2015, 2016 and 2017. The weeds collected per plot were gathered together and put in a polythene bag while the name/family of each weed were later carefully identified to determine their relative level of occurrence. The data on cocoa growth, yield production and labour cost were subjected to analysis of variance and the differences among treatment means were determined by the least significant difference at $5 \%$ probability level.

\section{Results and discussion}

\subsection{Growth and yield of cocoa}

Table 1 Mean plant height $(\mathrm{cm})$ of cocoa under different weed control and herbicide application rates

\begin{tabular}{|c|c|c|c|c|c|c|c|c|c|c|}
\hline \multirow[t]{2}{*}{ WAE } & \multicolumn{4}{|c|}{ Glyphosate (g a.i.ha-1 vlv) } & \multicolumn{4}{|c|}{ Paraquat (g a.i.ha-1 vlv) } & \multirow[t]{2}{*}{ Slashing } & \multirow[t]{2}{*}{$p=0.05$} \\
\hline & 480 & 720 & 960 & 1440 & 480 & 720 & 960 & 1440 & & \\
\hline 8 & 50.2 & 50.4 & 49.3 & 50.9 & 49.8 & 50.4 & 49.6 & 49.9 & 50.9 & NS \\
\hline 24 & 60.6 & 62.4 & 63.3 & 61.5 & 60.9 & 62.9 & 63.1 & 63.4 & 64.1 & NS \\
\hline 40 & 70.1 & 72.3 & 73.5 & 70.9 & 70.8 & 73.2 & 73.8 & 71.0 & 73.2 & NS \\
\hline 56 & 81.9 & 82.0 & 84.4 & 81.8 & 82.2 & 83.5 & 83.5 & 81.9 & 83.7 & $2.1^{*}$ \\
\hline 72 & 90.2 & 91.1 & 92.9 & 90.3 & 90.8 & 91.2 & 92.7 & 90.5 & 92.1 & $2.2^{*}$ \\
\hline 88 & 99.4 & 100.5 & 102.4 & 99.5 & 99.5 & 100.1 & 102.3 & 98.2 & 100.3 & $2.9^{*}$ \\
\hline 104 & 110.5 & 111.1 & 112.9 & 110.2 & 110.0 & 111.5 & 112.5 & 110.1 & 112.4 & $2.0^{*}$ \\
\hline 120 & 126.6 & 127.9 & 129.9 & 127.0 & 126.9 & 128.4 & 129.3 & 126.0 & 129.1 & $2.9^{*}$ \\
\hline 136 & 146.5 & 147.3 & 149.2 & 146.2 & 146.5 & 147.1 & 149.0 & 146.6 & 148.9 & $2.6^{*}$ \\
\hline 152 & 155.1 & 156.4 & 158.0 & 155.8 & 159.4 & 156.0 & 157.4 & 155.7 & 158.8 & $3.8^{*}$ \\
\hline
\end{tabular}
establishment.

Although, cocoa plants under manual weeding (slashing) had higher values than other treatments for most of the period of data collection, there were no significant differences $(\mathrm{p}=0.05)$ in cocoa height until 56 WAE when plants were about 15 months old because these were initially raised in the nursery for 6 months before field transplanting (Table 1). This was an indication of better exposure of cocoa plants to better aeration and sunlight under manual slashing due to complete removal of weeds. However, as the cocoa plants continued to grow, the effects of weed control methods on plant height gradually became significant $(\mathrm{p}=0.05)$. At $152 \mathrm{WAE}$, which symbolised the end of data collection, cocoa sprayed with both 480 and $1440 \mathrm{~g}$ a.i.ha-1 vlv glyphosate or paraquat had significantly lower mean plant height values $(\mathrm{p}=0.05)$ than their counterparts under manual weeding and other herbicides corresponding application rates, during the same period of time. It was also observed that application of herbicides (glyphosate and paraquat) at $960 \mathrm{~g}$ a.i. ha- 1 vlv for about four times per year ensured that the weed height was constantly lower than the cocoa height and helped to maintain constant exposure of plant leaves to adequate sunlight for optimum photosynthesis, and invariably kept competition from weeds to the barest minimum. 
Table 2 Cocoa stem girth ( $\mathrm{mm}$ ) under different weed control methods and herbicide application rates

\begin{tabular}{|c|c|c|c|c|c|c|c|c|c|c|}
\hline \multirow[t]{2}{*}{ WAE } & \multicolumn{4}{|c|}{ Glyphosate (g a.i.ha-1vlv) } & \multicolumn{4}{|c|}{ Paraquat (g a.i.ha-1vlv) } & \multirow[t]{2}{*}{ Slashing } & \multirow[t]{2}{*}{$p=0.05$} \\
\hline & 480 & 720 & 960 & 1440 & 480 & 720 & 960 & 1440 & & \\
\hline 8 & 8.9 & 9.6 & 10.8 & 8.0 & 9.0 & 9.1 & 10.1 & 8.1 & 10.6 & NS \\
\hline 24 & 14.9 & 15.3 & 16.3 & 14.5 & 14.8 & 14.0 & 16.7 & 15.6 & 16.9 & NS \\
\hline 40 & 25.8 & 26.5 & 27.9 & 25.4 & 25.4 & 26.5 & 27.0 & 25.5 & 26.6 & NS \\
\hline 56 & 32.4 & 34.3 & 35.2 & 32.9 & 32.8 & 33.7 & 34.8 & 32.8 & 35.0 & $2.1^{*}$ \\
\hline 72 & 43.8 & 45.9 & 46.8 & 43.9 & 44.4 & 46.0 & 46.8 & 43.9 & 45.9 & $2.5^{*}$ \\
\hline 88 & 55.9 & 56.2 & 58.0 & 55.8 & 56.9 & 57.0 & 58.1 & 56.3 & 57.2 & $1.9^{*}$ \\
\hline 104 & 65.8 & 66.8 & 69.2 & 66.0 & 67.0 & 68.9 & 68.7 & 65.1 & 68.8 & $2.9^{*}$ \\
\hline 120 & 77.6 & 80.3 & 81.8 & 78.2 & 77.9 & 79.0 & 81.2 & 77.0 & 81.2 & $3.1^{*}$ \\
\hline 136 & 97.6 & 98.0 & 99.0 & 97.5 & 97.0 & 96.8 & 98.4 & 97.2 & 98.5 & $1.9^{*}$ \\
\hline 152 & 108.3 & 108.3 & 110.6 & 107.9 & 107.8 & 108.9 & 109.7 & 108.7 & 109.8 & $2.0^{*}$ \\
\hline
\end{tabular}

Legend: $\mathrm{g}$ a.i. ha ${ }^{-1} \mathrm{vlv}=$ gram of active ingredient per hectare using very low volume; ${ }^{*}=$ significant; $\mathrm{NS}=$ not significant; WAE = weeks after establishment.

Cocoa stem girth performance pattern was similar to its plant height. While plants under manual weeding (slashing) and those sprayed at $960 \mathrm{~g}$ a.i.ha ${ }^{-1}$ vlv herbicides (glyphosate or paraquat) had significantly higher mean stem girth values than other treatments ( $p=0.05)$ from 56 WAE (Table 2). However, unlike plant height, cocoa maintained under $480 \mathrm{~g}$ a.i.ha ${ }^{-1} \mathrm{vlv}$ herbicides (glyphosate or paraquat) had smaller stem girth than those subjected to other treatments, during the same period of time. This scenario was observed throughout the period of the data collection. It has been reported that larger stem is a good indication of better dry matter production and accumulation in cocoa [14] which produces a higher chance of better survival and good establishment ability of cocoa in the field $[3,15]$.

Table 3 Mean number of leaves of cocoa under different weed control methods and herbicide application rates

\begin{tabular}{|l|l|l|l|l|l|l|l|l|l|l|}
\hline WAE & \multicolumn{3}{|c|}{ Glyphosate (g a.i. ha-1 vlv) } & \multicolumn{3}{l|}{ Paraquat (g a.i. ha-1 vlv) } & Slashing & p=0.05 \\
\hline & 480 & 720 & 960 & 1440 & 480 & 720 & 960 & 1440 & & \\
\hline 8 & 32 & 32 & 35 & 33 & 32 & 34 & 33 & 34 & 34 & NS \\
\hline 24 & 56 & 58 & 60 & 58 & 57 & 56 & 59 & 56 & 58 & NS \\
\hline 40 & 77 & 79 & 82 & 77 & 76 & 78 & 80 & 77 & 80 & $4^{*}$ \\
\hline 56 & 95 & 97 & 99 & 94 & 95 & 97 & 97 & 95 & 97 & $3^{*}$ \\
\hline 72 & 109 & 110 & 116 & 110 & 108 & 118 & 119 & 112 & 118 & $5^{*}$ \\
\hline 88 & 141 & 149 & 153 & 145 & 140 & 154 & 149 & 143 & 152 & NS \\
\hline 104 & 169 & 169 & 173 & 170 & 168 & 170 & 174 & 165 & 173 & $6^{*}$ \\
\hline 120 & 198 & 199 & 209 & 195 & 198 & 198 & 201 & 199 & 203 & $7^{*}$ \\
\hline 136 & 220 & 223 & 231 & 219 & 223 & 222 & 229 & 223 & 230 & $6^{*}$ \\
\hline 152 & 380 & 382 & 405 & 372 & 357 & 363 & 398 & 375 & 401 & $23^{*}$ \\
\hline
\end{tabular}

Legend: $\mathrm{g}$ a.i. ha $^{-1} \mathrm{vlv}=$ gram of active ingredient per hectare using very low volume; ${ }^{* * *}=$ significant; NS = not significant; WAE = weeks after establishment.

The leaf production pattern was similar to those of plant height and stem girth where there were no significant differences $(p=0.05)$ between treatments until around $56 \mathrm{WAE}$, except that there were also no significant differences 
between treatments at 88 WAE. Also, the number of leaves of cocoa plants raised under $960 \mathrm{~g}$ a.i.ha- $\mathrm{vl}^{-1 v}$ herbicides (glyphosate or paraquat) showed almost similar performance with those under manual weeding and significantly higher $(p=0.05)$ than the rest treatments (Table 3). Also similar to cocoa stem girth, plants under $480 \mathrm{~g}^{\text {a.i.ha- }}{ }^{-1} \mathrm{vlv}$ herbicides (glyphosate and paraquat) recorded significantly lower mean number of leaves $(p=0.05)$ than other treatments for most period of the data collection.

The higher morphological parameters (plant height, stem girth and number of leaves), which are direct indicators of overall growth of plant, recorded on manual labour and herbicides sprayed at $960 \mathrm{~g}$ a.i.ha ${ }^{-1} \mathrm{vlv}^{\mathrm{a}}$ herbicides (glyphosate or paraquat) were results of higher photosynthetic rate due to better exposure of plants to optimum moisture and chlorophyll content $[2,19]$. Application of herbicides (glyphosate or paraquat) at $960 \mathrm{~g}$ a.i. ha ${ }^{-1} \mathrm{v} / \mathrm{v}$ performed similar to manual weed control (slashing) during the early stage of cocoa establishment. Production of better growth and yield performance at $960 \mathrm{~g}$ a.i.ha ${ }^{-1} \mathrm{vlv}$ herbicides suggests that the development of the young cocoa trees were not adversely affected by their active ingredients, irrespective of whether it was systemic or contact herbicides. However, it also emphasises the benefits of adopting appropriate/recommended application rates for spraying. While herbicides sprayed at $480 \mathrm{~g}$ a.i. ha-1 ${ }^{-1}$ lv of glyphosate or paraquat were too low to effectively control emerging weeds for optimum cocoa growth, application at $1440 \mathrm{~g}$ a.i. ha- ${ }^{-1} \mathrm{vlv}$ seemed to be too reactive on the weeds and invariably negatively affected cocoa growth. The effectiveness of $960 \mathrm{~g}$ a.i. ha-1 $\mathrm{vlv}$ spraying rate for glyphosate or paraquat throughout the period of data collection must be a result of adequate concentrations of the active ingredients that were able to facilitate rapid killing of weeds and produced optimum cocoa growth similar to those under adequate manual weeding.

\subsection{Plant yield under different weed control}

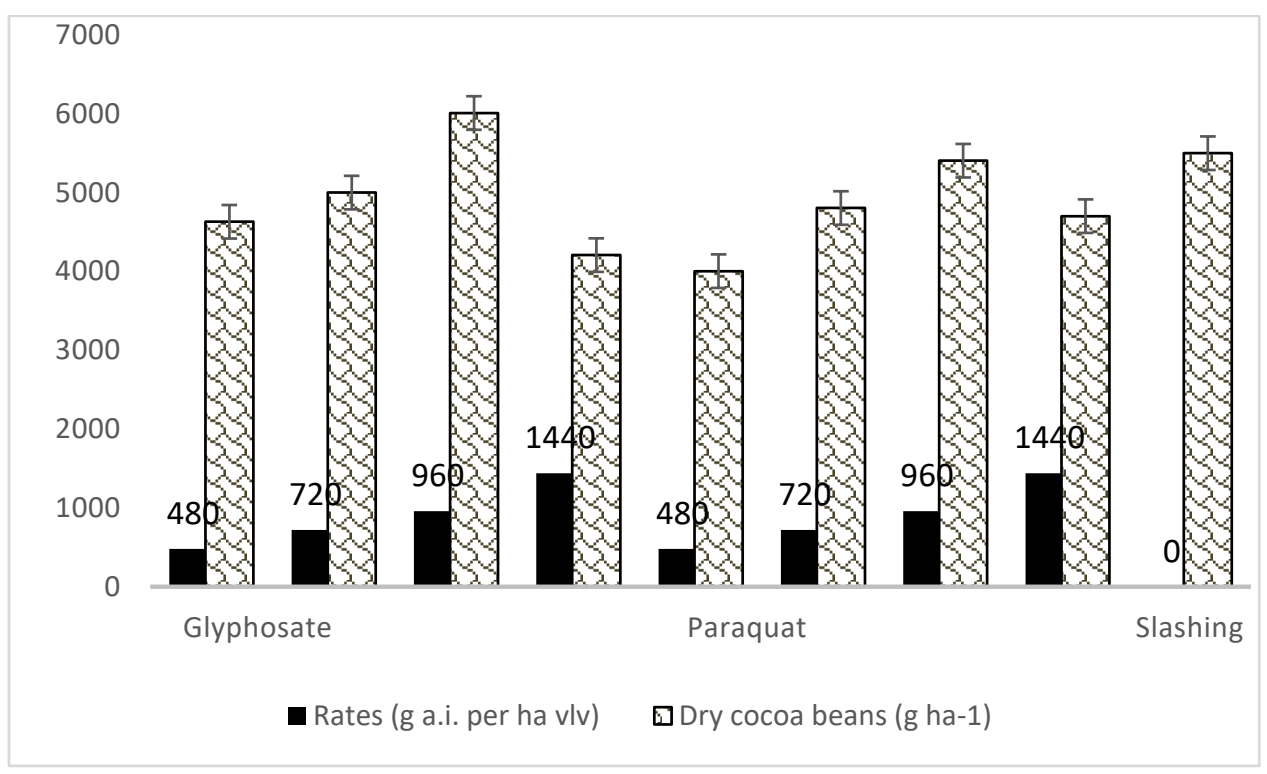

Figure 1 Total weight of dry cocoa beans $\left(\mathrm{g} \mathrm{ha}^{-1}\right)$ ) at 152 WAE under different weed control methods and herbicide application rates

The yield of plants at 152 WAE in the $3^{\text {rd }}$ year of establishment showed that despite similar morphological growth records, the weight of dry cocoa beans (at 8\% moisture content) obtained from $960 \mathrm{~g}$ a.i. ha ${ }^{-1} \mathrm{vlv}^{-}$glyphosate treated plots were significantly higher $(\mathrm{p}=0.05)$ than those from the same rate ( $960 \mathrm{~g}$ a.i. ha-1 $\mathrm{vlv}^{-1}$ ) of paraquat. One explanation to this is that application at $960 \mathrm{~g}$ a.i. ha ${ }^{-1}$ vlv glyphosate effectively kept weed growth below economic injury level without immediate or residual adverse effects on the growth of cocoa and resulted in the higher cocoa yield above the farmers' practice of manual weed control. The result contradicts reports that showed no significant differences in the initial yields of young cocoa plots between chemical and manual weed control $[12,16]$. On the other hand, our result also showed that yield performance from the manually weeded plots and those sprayed with $960 \mathrm{~g} \mathrm{a}$.i. ha-1 $\mathrm{vlv}^{-1}$ paraquat were not significantly different $(\mathrm{p}=0.05)$ at $152 \mathrm{WAE}$ thereby revealing that performance of glyphosate and paraquat on cocoa planation are not always the same. Manual weeding through slashing by cutlass had similar pattern of effect on the cocoa morphological performance as $960 \mathrm{~g}$ a.i. ha ${ }^{-1}$ vlv herbicide. The result confirmed that effective and timely weed control are critical to obtaining highest potential growth and development in cocoa, and also suggested the best choice of sprayer and the nozzle for spraying herbicides.. Also, the effectiveness of both glyphosate and paraquat naturally decline with time and do not exhibit any residual effects on crops, if sprayed at recommended rates $[7,12]$. The possible disruption of aromatic amino acid synthesis due to the strong drift of glyphosate might have also 
contributed to lower cocoa yield under $1440 \mathrm{~g}$ a.i. ha- ${ }^{-1} \mathrm{v} / \mathrm{v}$ glyphosate since amino acids are known to play a vital role in fruit set and retention $[13,18]$. Consequently, cocoa performance under $1440 \mathrm{~g}$ a.i. ha ${ }^{-1}$ vlv application rate for glyphosate and paraquat with growth and yield that were below optimum level are inimical to plant development and therefore not recommended for cocoa plantation.

\subsection{Cost of treatment}

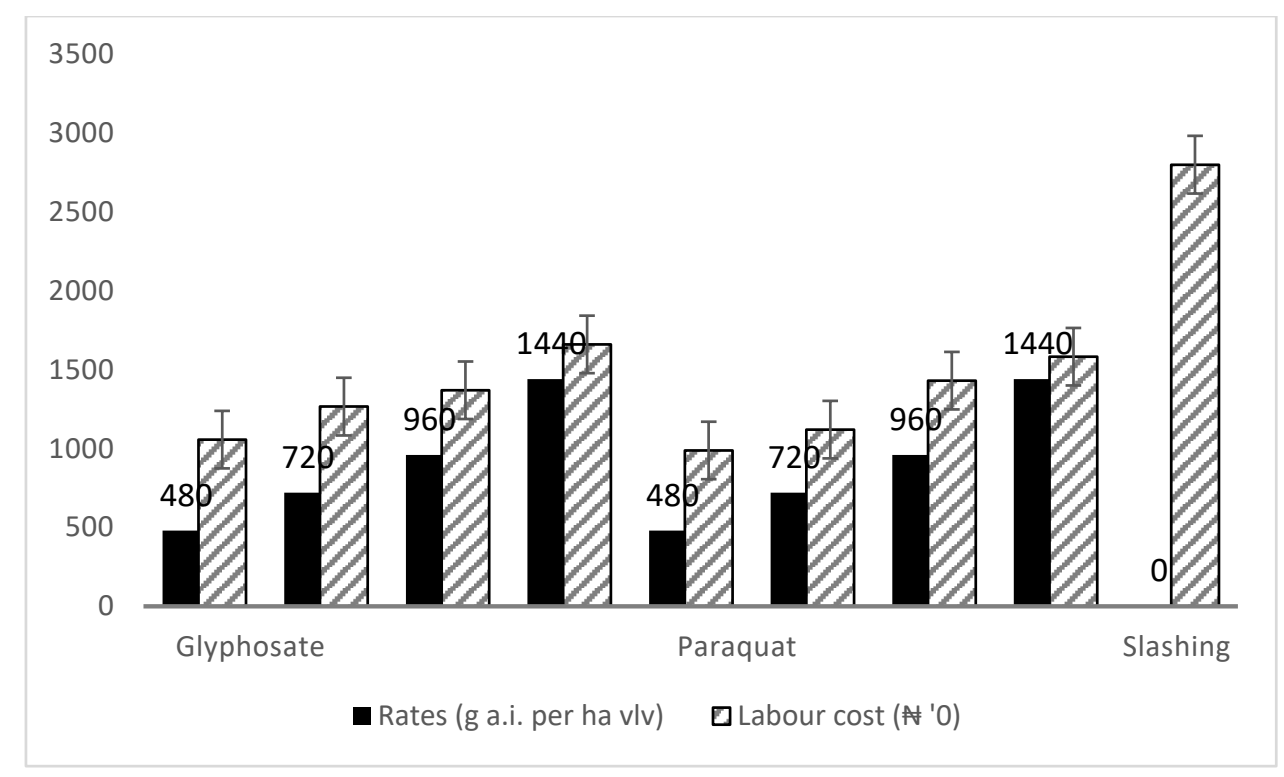

Figure 2 Total cost ( $\mathrm{N}^{\prime} 00$ ) of weed control methods at different herbicide application rates

Manual weeding recorded the highest cost of weed control per hectare which was significantly higher $(\mathrm{p}=0.05)$ than cost of either glyphosate or paraquat used at any rate (Figure 2). Although, there were significant differences ( $\mathrm{p}=0.05)$ in the cost of weed control at 480 and $1440 \mathrm{~g}^{\text {a.i.ha }}{ }^{-1} \mathrm{vlv}$ herbicides (glyphosate or paraquat), these were marginal compared to the higher differences between the cost of applying herbicide at any rate and that of manual weed control. The amount of active ingredient required at each application rate was the major factor which determine their cost differences, especially since labour cost per hectare for spraying either glyphosate or paraquat is not significantly different. The results revealed that it was a bit cheaper to use paraquat than glyphosate when applied at similar gram of active ingredient per hectare, the cost of manual weed control, which is best recommended for young cocoa, was more than double the cost of $960 \mathrm{~g}$ a.i.ha ${ }^{-1} \mathrm{vlv}$ of glyphosate or paraquat. These average concentration rates would also exert relatively less adverse effects on soil fauna and also lead to lower drift concentration, which has been shown to affect fruit set and retention $[13,18]$. This probably explains why dry bean yield from plots treated with this average rates was higher. In fact, the dry bean yield $\left(\mathrm{g} \mathrm{ha}^{-1}\right)$ from manually weeded cocoa plots was almost the same with those obtained from the $960 \mathrm{~g}$ a.i. ha-1 $\mathrm{v} / \mathrm{v}$ either glyphosate or paraquat sprayed plots.

Knowledge on early detection of weed incidence on the crop is critical for understanding the basic mechanisms to effectively deal with all underlying crop-weed competitions [11]. In the present study, clean weeding at least, four times a year, seemed to be the best treatment for cocoa survival and growth but the cost to the farmer was high and sometimes, more than double the cost incurred when glyphosate or paraquat were used to control. In order to effectively remove weed competition from cocoa, farmers should ensure that cocoa trees are adequately ring weeded at $1 \mathrm{~m}$ width or more before herbicides are sprayed.

\subsection{The relative occurrence of weed species between 2015 and 2017}

The relative occurrence of weed species infesting the cocoa crop under each treatment is presented in Table 4 . Occurrence of different weeds species at the experimental sites varied in frequency and appearance with those in the family of Euphorbiaceae having highest level of occurrence among the broad-leaf while Poaceae and Cyperaceae recurring more frequently in the grasses and sedges, respectively. Leucas martinicensis, Ageratum conyzoides, Chromoleana odorata, Portulaca oleraceae and Eleusine indica were the most dominant weed species occurring across all the treatments during the initial stage of field establishment in 2015. Although, weed incidence in manual weeded plots remained almost constant throughout the period of the trail, in 2016 and 2017 there were little changes in the composition of plots treated with both glyphosate and paraquat, irrespective of their application rates. For instance, 
weed species like Amaranthus viridis, Aspilia Africana and Cyperus difformis which were initially not part of weed composition in pre-treatment era in 2015 gradually surfaced and established their presence on both glyphosate and paraquat treated plots by 2017. This was a confirmation that a particular method of control is more suitable for certain weed species. Famaye et al., [6] also reported similar variation in the level of weed infestation in the second year of establishment in a Coffee/Oil palm intercropped plot in Nigeria

Table 4 Weed species and their levels of occurrence at the experimental sites

\begin{tabular}{|c|c|c|c|c|c|c|c|c|c|c|}
\hline \multirow[t]{3}{*}{ Weed species } & \multirow[t]{3}{*}{ Family } & \multicolumn{9}{|c|}{ Level of occurrence } \\
\hline & & \multicolumn{3}{|c|}{2015} & \multicolumn{3}{|c|}{2016} & \multicolumn{3}{|c|}{2017} \\
\hline & & $\mathrm{G}$ & $\mathrm{P}$ & $\mathrm{S}$ & $\mathrm{G}$ & $\mathrm{P}$ & $\mathrm{S}$ & $\mathrm{G}$ & $\mathrm{P}$ & $\mathrm{S}$ \\
\hline Leucas martinicensis & Lamiaceae & +++ & +++ & +++ & ++ & +++ & +++ & +++ & +++ & +++ \\
\hline Ageratum conyzoides & Asteraceae & +++ & +++ & +++ & ++ & ++ & +++ & ++ & ++ & +++ \\
\hline Acethospermum hispidium & Acanthaecea & ++ & ++ & ++ & + & + & ++ & ++ & + & ++ \\
\hline Euphorbia heterophylla & Euphorbiaceae & ++ & ++ & ++ & ++ & ++ & ++ & - & + & ++ \\
\hline Gomphrena celosioides & Amaranthaceae & + & + & + & + & + & + & - & ++ & + \\
\hline Chromoleana odorata & Asteraceae & +++ & +++ & +++ & +++ & +++ & +++ & ++ & ++ & +++ \\
\hline Tridax Procumbens & Euphorbiaceae & ++ & ++ & ++ & - & + & ++ & - & - & ++ \\
\hline Amaranthus viridis & amaranthaceae & - & - & - & + & - & - & ++ & + & - \\
\hline Aspilia Africana & Asteraceae & + & + & + & ++ & ++ & + & +++ & +++ & + \\
\hline Portulaca oleraceae & Portulacaceae & +++ & +++ & +++ & +++ & +++ & +++ & + & + & +++ \\
\hline Hyptis lanceolata & Lamiaceae & ++ & + & ++ & ++ & + & ++ & - & + & ++ \\
\hline Commelina benghalensis & Commelinaceae & ++ & ++ & + & ++ & ++ & + & - & - & ++ \\
\hline Digitaria horizontalis & Poaceae & ++ & ++ & ++ & ++ & ++ & ++ & + & + & ++ \\
\hline Eleusine indica & Poaceae & +++ & +++ & +++ & ++ & ++ & +++ & + & + & +++ \\
\hline Chloris pilosa & Gramineae & ++ & ++ & ++ & - & - & ++ & - & - & ++ \\
\hline Cyperus difformis & Cyperaceae & - & - & - & + & + & - & + & + & - \\
\hline
\end{tabular}

\section{Conclusion}

Due to of the fragility of young cocoa plants, clean slashing or manual weeding is sometimes preferred for the first 6 months after cocoa establishment, especially at a small scale level. Application of either glyphosate or paraquat at recommended rates is also adequate for controlling weeds during early plantation period, as long as the young plants are manually ring-weeded before herbicides are sprayed. Although, clean slashing for at least, four times in a year resulted in growth and cocoa yield level similar to those obtainable on glyphosate or paraquat sprayed at $960 \mathrm{~g}$ a.i. ha1 vlv four times per year, improper application of herbicides, in terms of inappropriate quantity and frequency can result in below optimum growth and low yield performance of cocoa, and should be avoided. This trial had also established that spraying either glyphosate or paraquat at $960 \mathrm{~g}$ a.i. ha-1 vlv will effectively keep weed growth below economic injury level, produce higher yield than manual weeding and eventually result into higher cost-benefit ratio than manual weed control. While, the cost of spraying glyphosate was higher but not significant than that of paraquat at similar rates, glyphosate sprayed at $960 \mathrm{~g}$ a.i. ha-1 vlv, produced cocoa yield that was significantly higher than that of paraquat at the same application rate. Due to its efficacy at producing higher yield, glyphosate at $960 \mathrm{~g}$ a.i. ha- $1 \mathrm{vlv}$ rate, which is equivalent to 2 litre of glyphosate in 120 litre of water, is therefore recommended for weed control in the early years of cocoa establishment, especially when cocoa is cultivated at a large scale level. 


\section{Compliance with ethical standards}

\section{Acknowledgments}

The authors appreciate the Executive Director of Cocoa Research Institute of Nigeria, Ibadan for permission to publish this research work.

\section{Disclosure of conflict of interest}

The authors declare no conflicts of interest regarding the publication of this paper.

\section{References}

[1] Adigun, J.A. and Lagoke, S.T.O. Weed control in transplanted rainfed and integrated tomato in the Nigerian Savanna. Nigerian Journal of weed Science, 2003; 16: 23-29. [Google Scholar]

[2] Alvim, P., DE, T. and Alvim, R. Environmental requirements of cocoa with emphasis on response to shade and moisture: Proceeding International conference on cocoa and coconuts. The incorporated Society of Planters. Kuala Lumpur, Malaysia. 1980:93-111.

[3] Amoah, F.M., Opoku-Ameyaw, K., Osei-Bonsu, K. and Oppong, F.K. The effect of seedling age on the survival rate of transplanted bare-rooted cocoa seedlings. Proceedings, 13th International Cocoa Research Conference, Kota Kinabalu, Malaysia: 1215-1219. 2001

[4] Bonaparte A, Toseafa K Rehabilitation trial. Annual Report, Cocoa Research Institute of Ghana, 1972;73: 26.1975

[5] Efron, Y., Epaina, P., Tade, E. and Marfu, J. The Relationship Between Vigour, Yield and Yield Efficiency of Cocoa Clones Planted at Different Densities, Proceedings International Workshop on Cocoa Breeding for Improved Production Systems, 19-21 October 2003; Accra, Ghana: 92-102

[6] Famaye, A.O., Adeosun, S.A., Ayegboyin, K.O., Adejobi, K.B., Akanbi, O.S.O. and Okunade, A.F. Evaluation of Weed incidence and Biomass in Coffee Intercropped with Oil palm in Avenue and Hollow square Arrangement in Nigeria, American Journal of Plant Sciences, 2020;11: 276-284. https://doi.org/10.4236/ajps.2020.112021

[7] Franz, J.E., Mao, M.K. and Sikorski, J.A. Glyphosate: a unique global herbicide. American Chemical Society, Washington, DC: 653. 1997

[8] Friesen, G. and Shebeski, L.H. Economic Losses Caused by Weed Competition in Manitoba Grain Fields. I. Weed species, their relative abundance and their effect on crop yields. Canadian Journal of Plant Sciences, 1960; 40: 457-467. www.nrcresearchpress.com

[9] Hamzat, R.A., Olaiya, A.O., Sanusi, R.A. and Adedeji. A.R. State of Cocoa Growth, Quality and Research in Nigeria: Need for Intervention. A technical presentation at the Biannual partnership programme of the World Cocoa Foundation, Belgium: 522006

[10] ICCO Quarterly Bulletin of Cocoa Statistics, Vol. XLV, No. 1. ICCO Cocoa year 2018/19, published 28/02/2019, available at: https://www.icco.org 2019

[11] Imoloame, E.O. Evaluation of herbicide mixtures and manual weed control method in maize (Zea mays L.) production in the Southern Guinea agro-ecology of Nigeria. Cogent Food \& Agriculture, 2017; 3(1):1375378. https://doi.org/10.1080/23311932.2017.1375378

[12] Magda, M.K., Ayman, E.S., Arafa, H.E. and Ahmed, S.E.M. Effect of humic acid and amino acids on pomegranate trees under deficit irrigation I: Growth, flowering and fruiting. Journal of Horticultural Science and Ornamental Plants, 2012; 4(3):253-259.

[13] Konlan, S., Quaye, A.K., Pobee, P., Amon-Armah, F., Dogbatse, J.A., Arthur, A., Fiakpornu, R. and Dogbadzi, R. Effect of weed management with glyphosate on growth and early yield of young cocoa (Theobroma cacao L.) in Ghana. African Journal of Agricultural Research, 2019; 14(28): 1229-1238. http://www.academicjournals.org/AJAR

[14] Mehmood, T., Ahmad, W., Ahmad, K.S., Shafi, J., Shehzad, M.A. and Sarwar, M.A. Comparative Effect of Different Potting Media on Vegetative and Reproductive Growth of Floral Shower (Antirrhinum majus L.) Tahir. Universal Journal of Plant Science, 2013; 1(3): 104-111.

[15] Oppong, F.K., Opoku-Ameyaw, K., Ofori-Frimpong, K. and Owusu-Ansah, F. Effects of polybag size and foliar application of urea on cocoa seedling growth. Ghana Journal of Agricultural Science, 2007; 40 (2): 207-213. 
[16] Oppong, F.K., Sarfo, J.E., Osei-Bonsu, K. and Amoah, F.M. Effects of sulfosate on weed suppression, cocoa pod set and yield of cocoa and coffee. Ghana Journal of Agricultural Science, 2006; 39 (2): 115-122.

[17] Remison, S.U. Effect of weeding and nitrogen treatments on yield of maize in Nigeria. Weed Research, 1979; 19: 71-74. [Crossref], [Web of Science ®], [Google Scholar]

[18] Salem, M.A. Improved growth, productivity and quality of tomato (Solanum lycopersicum L.) plants through application of shikmic acid. Saudi Journal of Biological Sciences, 2013; 20 (4): 339-345.

[19] Shinji, S., Andrew, D.N., Shawaeng, R. and Narong, C. Imrpovement in water-holding capacity and structural stability of a sandy soil in Northeast Thailand. Arid land Research and Management, 2007; 21: 37-19.

[20] Tamado, T., Ohlander, L. and Milberg, P. Interference by the weed Parthenium hysterophorus L. with grain sorghum: influence of weed density and duration of competition. International Journal of Pest Management, 2002; 48(3): 183-188. http://www.tandf.co.uk/journals

[21] Wood, G.A.R. and Lass, R.A. Cocoa, 4th Edition, London Longman: 620.1985

\section{Author's short biography}

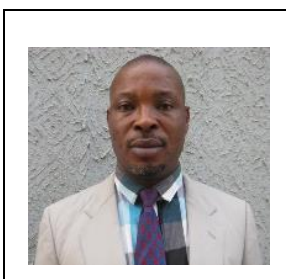

Dr. Ayegboyin, K.O.

Dr Kayode Olufemi Ayegboyin was born on 21 May 1975 at Ogbomosho, Oyo State, Nigeria. He holds BSc (Hons) in Agriculture and MSc in Crop Science of the University of Ibadan, Ibadan, Nigeria in 1997 and 2005, respectively. He proceeded to the University of Reading, Reading, United Kingdom in 2008 and graduated in 2012 with PhD in Plant Science. He joined the services of Cocoa Research Institute of Nigeria, Ibadan as a Research Officer grade 2 in 2002 and presently awaiting his promotion to Assistant Director with the Institute. He has over 20 research publications on cocoa agronomy, breeding and physiology in many reputable research journals around the world. 